\title{
The Accountability Type of Endowment (Waqf) Institutions in ASEAN Countries
}

\author{
Dodik Siswantoro $^{1^{*}}$ \\ ${ }^{1}$ Faculty of Economics and Business, Universitas Indonesia \\ Email: dodik.siswantoro@ui.ac.id
}

\begin{abstract}
This research aimed to analyze the accountability type of endowment institutions in ASEAN countries. Each country may have specific accountability characteristics as affected by its milieu. The research used the qualitative method and is based on the post-positivist paradigm. Data collection is based on interviews, and unit analysis of endowment institutions are collected from three countries (Indonesia - four institutions, Malaysia - two institutions and Singapore - one institution). The result showed that only Indonesia cannot be classified for accountability type, followed by Malaysia, while Singapore may have a clear pattern of accountability logic.
\end{abstract}

Type of paper: Empirical

Keyword: Accountability, waqf, type, ASEAN, culture.

\section{Introduction}

The study of accountability logic type on endowment institutions in Indonesia has been discussed by Siswantoro and Haula (2015). They found that those institutions could not be identified clearly, whether it belonged either to the unitary or pluralist logic type as proposed Coule (2013).

In Indonesia, private and government institutions can manage endowment (waqf) institutions. Each institution type has different characteristics that may result in different accountability logic type. Coule (2013) uses three dimensions while Siswantoro and Haula (2015) add up to five dimensions each of which contains two until three aspects. In Indonesia, accountability logic type cannot be identified as it comes from different backgrounds.

To see the consistency of the result, the unit analysis was broadened to other countries in ASEAN such as Malaysia and Singapore. Those countries have similarity to the historical background of Islamic finance institution development. Malaysia has similar culture and people, which are mostly traditional and Malayan, while Singapore may be a little bit different in which Muslim in the country is not the majority. However, those countries are the members of ASEAN that share similar characteristics.

The objective of this paper is to analyze the accountability logic type of endowment institutions in ASEAN countries such as Indonesia, Malaysia and Singapore. This research can enrich 
Table 1. Differences in logic structure

\begin{tabular}{|c|c|}
\hline Unitary logic & Pluralist logic \\
\hline \multicolumn{2}{|c|}{ 1. Control and conflict } \\
\hline $\begin{array}{l}\text { a. Emphasis on development of policies and procedures to control } \\
\text { work behavior } \\
\text { b. Conflict is viewed as illegitimate and dysfunctional } \\
\text { c. Elevation of organizational history to socialize employees } \\
\text { for sharing leaders' benefits, assumptions and vision for } \\
\text { organization. }\end{array}$ & $\begin{array}{l}\text { a. Emphasis on negotiated social relations between different } \\
\text { organizational groupings for purposes of learning and } \\
\text { development } \\
\text { b. Conflict viewed as inevitable and a potential source of } \\
\text { creativity } \\
\text { c. Deliberate creation of opportunities to test and challenge own } \\
\text { and others' views and assumptions }\end{array}$ \\
\hline 2. Separation of elites & 2. Demystification of elites \\
\hline $\begin{array}{l}\text { d. Strategic decision-making restricted to organizational elites } \\
\text { e. Enforcement of hierarchy through formal structures } \\
\text { f. Restricted face-to-face contact between staff and board }\end{array}$ & $\begin{array}{l}\text { d. Participation in strategic decision-making by all internal } \\
\text { groupings } \\
\text { e. Status of internal groupings based on centrality to service work/ } \\
\text { mission rather than hierarchical position } \\
\text { f. Promotion of direct face-to-face contact between staff and board }\end{array}$ \\
\hline \multicolumn{2}{|c|}{ 3. Purposes and boundaries of accountability } \\
\hline 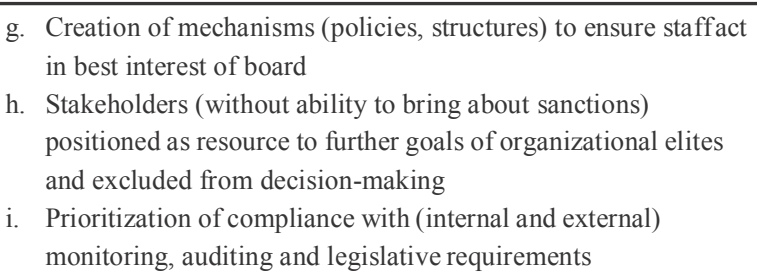 & $\begin{array}{l}\text { g. Creation of processes to ensure diversity of voices influence } \\
\text { organizational activity } \\
\text { h. Attention paid to power and politics of (internal and external) } \\
\text { stakeholder involvement } \\
\text { i. Involvement of stakeholders in decision-making seed as source } \\
\text { of legitimacy }\end{array}$ \\
\hline
\end{tabular}

the previous research. This paper begins with an introduction and literature review. The third section explains the methodology of the research. The fourth section explains the research findings. The final section concludes the study.

\section{Literature Review}

Siswantoro and Haula (2015) have shown that accountability logic type of endowment institutions in Indonesia has a different emphasis on logic. They do not refer to unitary or pluralist logic like Coule (2013) has mapped. Accountability in some definitions by researchers can be defined as showing responsibility to the public. This definition was inferred by Lipman and Lipman (2006) and Fox and Brown (1998). Stakeholders can be the important aspect of reporting by institutions (Ebrahim, 2005; Tremblay-Boire and Prakash, 2014).

The issue of logic accountability proposed by Coule (2013) is more likely the characteristic of accountability. She grouped accountability logic type based on Fox (1996) into two groups, i.e. unitary and pluralist logic (see table 1).

As discussed by Siswantoro and Haula (2016), in Islamic perspective, accountability logic adds the government and shari'ah compliance dimensions which refers to Iqbal and Lewis (2009). Despite those new dimensions, the accountability logic of endowment institutions in Indonesia cannot be identified clearly, whether it is either similar to unitary or pluralist logic.

Although endowment institutions are not for profit organizations, they still need to generate maximum income to finance their social organization. Therefore, the management (Sawant, 2010) and governance (Olson, 2003) of endowment institution management are similar to mutual fund, insurance, and pension fund institutions as is the case of financial management. 
Table 2. Dimension of Accountability

\begin{tabular}{|c|c|c|c|}
\hline Element & Unitary logic & Pluralist logic & Islamic \\
\hline \multirow[t]{2}{*}{ Control and conflict } & $\begin{array}{l}\text { Emphasis on policies and } \\
\text { procedures. }\end{array}$ & Negotiated social relations. & Government is more regulated. \\
\hline & $\begin{array}{l}\text { Conflict is illegitimate and } \\
\text { dysfunctional. } \\
\text { History as shared value. }\end{array}$ & $\begin{array}{l}\text { Conflict as source of creativity. } \\
\text { Creation of opportunities. }\end{array}$ & $\begin{array}{l}\text { Conflict is common in private. } \\
\text { Change is inevitable. }\end{array}$ \\
\hline Elites & $\begin{array}{l}\text { Restricted decision-making. } \\
\text { Hierarchy through formal } \\
\text { structures. } \\
\text { Restricted contact employee and } \\
\text { board. }\end{array}$ & $\begin{array}{l}\text { Strategic decision-making by all } \\
\text { internal groupings. } \\
\text { Centrality to service work/ } \\
\text { mission. } \\
\text { Face-to-face contact between } \\
\text { employees and board. }\end{array}$ & $\begin{array}{l}\text { Decision by elites and } \\
\text { participation on priority. } \\
\text { Private emphasizes on } \\
\text { partnership and flexibility. } \\
\text { Private is borderless. }\end{array}$ \\
\hline Government evaluation & n.a & n.a & $\begin{array}{l}\text { Government as coordinator anc } \\
\text { proactive in monitoring. } \\
\text { Government must active in } \\
\text { evaluation. }\end{array}$ \\
\hline \multirow[t]{3}{*}{$\begin{array}{l}\text { Purposes and boundaries of } \\
\text { accountability }\end{array}$} & Creation of mechanisms. & Creation of processes. & $\begin{array}{l}\text { Based on priority and } \\
\text { regulation. }\end{array}$ \\
\hline & $\begin{array}{l}\text { Stakeholder excluded decision- } \\
\text { making. }\end{array}$ & Stakeholder involvement. & $\begin{array}{l}\text { Program alignment with } \\
\text { internal. }\end{array}$ \\
\hline & Prioritization of compliance. & $\begin{array}{l}\text { Stakeholders in decision- } \\
\text { making as legitimate. }\end{array}$ & Management authority. \\
\hline Shari'ah compliance and audit & n.a & n.a & $\begin{array}{l}\text { Formal shari'ah supervision. } \\
\text { Internal shari'ah audit. }\end{array}$ \\
\hline
\end{tabular}

Source: Siswantoro and Haula (2015)

Hence, the characteristic of accountability should be more likely the unitary logic, which focuses on specific stakeholders. As in endowment institutions there is no shareholder, the accountability target may be different from the company shareholder basis.

Endowment institutions need huge funds to achieve economic of scale management. The problem may occur if the funds are not sufficient. On the other hand, these institutions need similar treatment and management like professional companies. This has been studied by Sawant (2010) and Leibowitz et al. (2010). From the history of Islamic legacy, endowment was practiced in huge amount and capital like dates farm which needs professional and good management.

From Siswantoro and Haula (2015)'s study, it is revealed that the two-dichotomous logic (developed by Bradshaw et al. (2007); Horswill (2013)) may not be relevant as endowment institution cannot be identified as one accountability logic. The study of accountability in a not-for-profit organization may be subjective and limited to specific issue in their milieu. However, this organization should be open and transparent to the public so everyone and related parties can access their activities and report. This can reduce asymmetric information to the public (Cordery, 2013).

The result of Siswantoro and Haula's study (2015) can be seen in table 2. The discussion is described as follows:

1. Dimension of control and conflict for endowment institution has different characteristic from unitary and pluralist logic, as many endowment institution are managed by the private sector and have relatively simple management.

2. Elites' dimension may be similar to pluralist logic but not for centrality issues for services and work mission.

3. The Government acts as the coordinator and is active in monitoring. 
Table 3. Dimensions of Islamic Accountability

\begin{tabular}{ll}
\hline Dimension & Islamic Perspective \\
\hline Control and conflict & $\begin{array}{l}\text { Based on policy and procedure, quick response for new activity } \\
\text { Conflict is permissible as it adds value to organizational } \\
\text { development } \\
\text { Quick changes are needed to anticipate new trends }\end{array}$ \\
\hline Elites & $\begin{array}{l}\text { Decision-making involves staff; decisions are based on shura by } \\
\text { elites }\end{array}$ \\
& $\begin{array}{l}\text { Flexible and quick in responding to services by stakeholders } \\
\text { Relationship between staff and management must be optimum }\end{array}$ \\
\hline Government evaluation & $\begin{array}{l}\text { Government role must be active in coordinating and reporting to } \\
\text { society }\end{array}$ \\
& Evaluation must be routine and site visits are a must \\
\hline Purposes and boundaries of accountability & $\begin{array}{l}\text { Strategic program plans can be from society; focus on service for } \\
\text { beneficiaries }\end{array}$ \\
Stakeholders can be involved if benefited \\
Need cooperation and coordination with others without ignoring \\
the organization's vision
\end{tabular}

4. Purposes and boundaries of accountability are likely to be similar to unitary logic but stakeholder may be involved in proposing programs.

5. Shari'ah compliance needs formal supervision from institution, while shari'ah audit can be performed internally.

Then, proposal of Islamic accountability can be seen in table 3 . The discussion is described as follows:

1. Regarding control and conflict, as endowment institution in Indonesia is relatively new, it needs a quick response to adapt to the changes very quick and dynamic changes. Different opinions are permissible since it can give a better solution to institution.

2. Concerning the relation of elites and staff, flexible discussion and proposition of ideas between staff and management is encouraged to achieve better result.

3. Regarding the government evaluation, the government should be active in monitoring and evaluation of endowment institutions. Site visit is mandatory performed

4. Related to the purposes and boundaries of accountability, stakeholders can be involved in preparing the strategic institution without intervening the institution's vision.

5. To ensure Shari'ah compliance and audit, supervision should be on shari'ah basis. Shari'ah audit should be conducted by an independent body.

\section{Research Methodology}

The research employs the qualitative method and post-positivist paradigm. Data was taken by interviewing four endowment institutions in Indonesia, two in Malaysia and one in Singapore. Interview questions are based on the study of Siswantoro and Haula (2016) to show the consistency of the issue.

The data was analyzed by comparing the interviews in the three countries. Different responses can be additional codes from previous codes conducted by Siswantoro and Haula (2016). Codes are based on important issues during the interview from respondents. 
To provide trust, such tools are applied to ensure credibility, transferability, dependability, and conformability (Lincoln and Guba, 1985). Credibility is ensured by checking different sources. Transferability is ensured by multiple cases while Dependability comes by formulating the proper case study protocol and conformability uses the record as proof.

\section{Results and Discussion}

Endowment institutions especially for cash waqf institutions focus on profit maximization as it would be used for social activities. To earn higher income, endowment should be able to manage the fund efficiently and in huge amount (Siswantoro, 2017). The characteristic of accountability logic may be different for each endowment institution. The study of logic accountability does not necessarily determine the quality of accountability (Siswantoro and Haula, 2016).

This study is based on Coule's study (2013) with Islamic teaching paradigm proposed by Siswantoro and Haula (2016). The dimensions and aspect would be still the same as the previous study conducted by Siswantoro and Haula (2016). The analysis is described as follows:

\subsection{Control and conflict}

Control and conflict dimension has three aspects of emphasis, conflict, and innovation. Each aspect can consist of three up to five nodes. Procedure is the main concern for each country. Indonesia and Malaysia may have similarity in some nodes but they have differences in shari'ah nodes in which Malaysia has issues in shari'ah node. Only Indonesia has "not have" node which means that they do not have case of emphasis on policies and procedure (see figure 1).

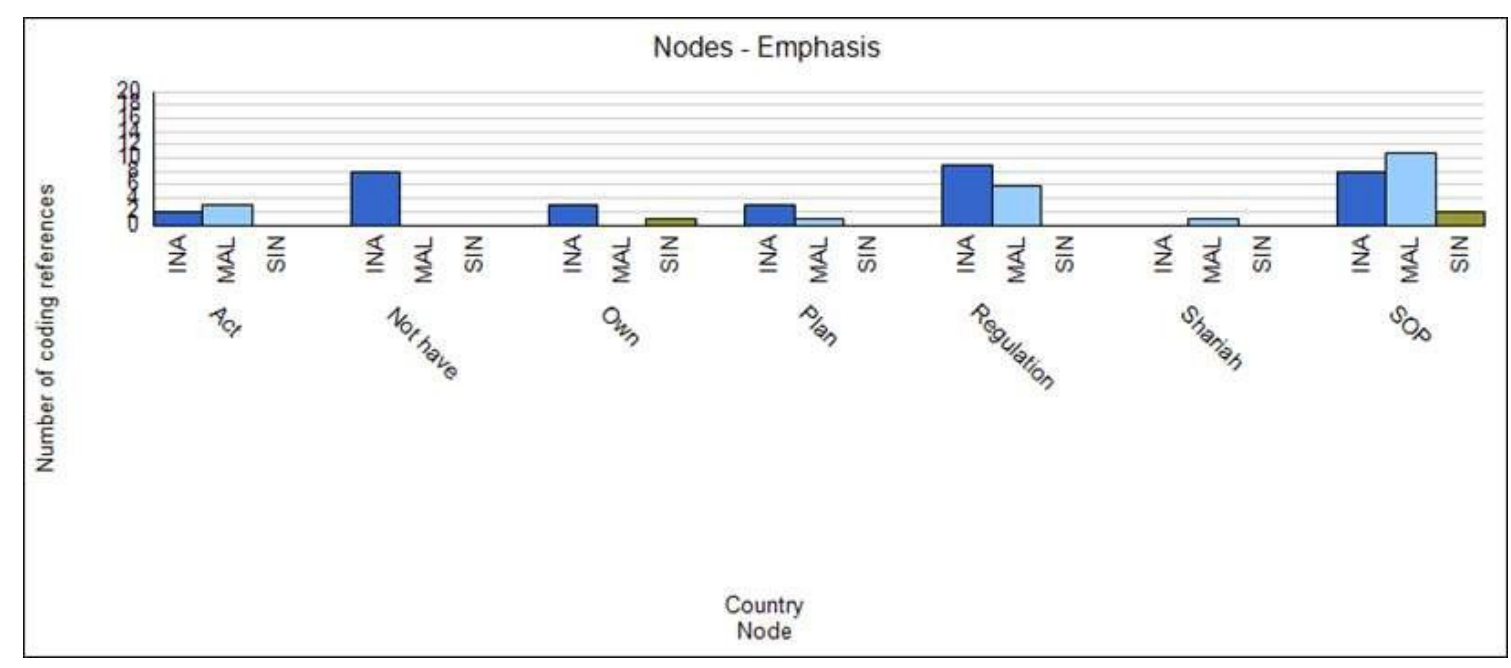

Source: Data

Figure 1. Control and conflict - Emphasis

In conflict aspect, only Malaysia and Singapore share similar node in "common" which means that different opinions between staffs and management are common issues. In fact, in other nodes, Indonesia and Malaysia share similar issues in conflict aspect. This means that both countries share similar aspects in control and conflict. 


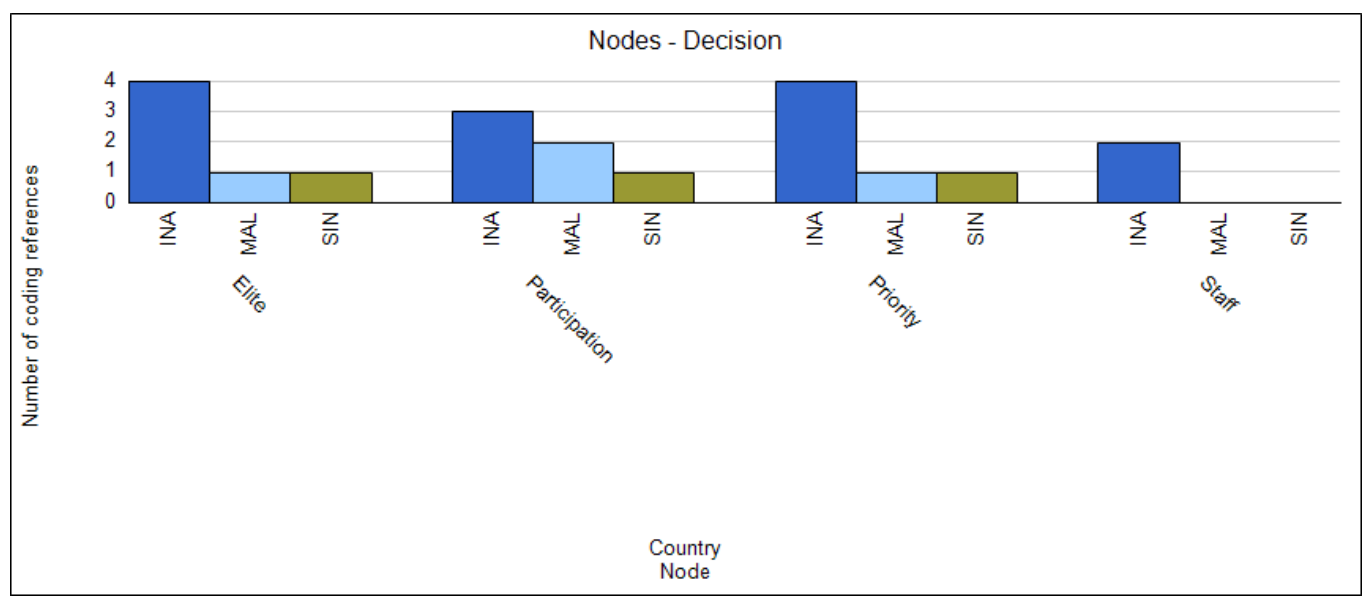

Source: Data

Figure 2. Elites - Decision

In innovation aspect, only Indonesia has "motivation" node. This means that history has a role in motivation to develop endowment in Indonesia. Indonesia and Singapore share similar nodes in "conflict" node, which means that it is not a big problem to have different opinions between staffs and management. In general, Malaysia and Indonesia share more similar node issues.

\subsection{Elites}

Elites dimension has three aspects: decision, relationship and structure. In decision aspect, almost all countries share similar nodes in decision aspect. In exception of the "staff" node in Indonesia, the staff can propose idea to the management and have more opinions in endowment institution. As Indonesia is inclined to private sector, staff has flexibility to express their opinion (see figure 2).

For structure aspect, Malaysia and Indonesia share similar nodes, while Singapore has similarity at hierarchy. However, it is only in Indonesia that members of institution are treated as partners to develop endowment institution. In relationship aspect, only Singapore has border between staff and management. This is consistent with Indonesia in "limited" node. The structure may cause limited relationship in the endowment institution.

\subsection{Government Evaluation}

The different governmental systems between Indonesia, Malaysia and Singapore may implicate to endowment institution reporting and evaluation mechanism. This also is reflected in figure 3. The pattern of three countries is random. In fact, Singapore claimed that role of the government is ignored as they do not concern on this case. However, in Indonesia the role is "seldom" node in which the evaluation is not routinely checked.

In evaluation aspect, only Indonesia has different node, which is not touched by Malaysia and Singapore. They are "informal" and "passive report" nodes. This shows that the monitoring and reporting system for endowment institution in Indonesia is not so good compared to other countries like Malaysia and Singapore. 


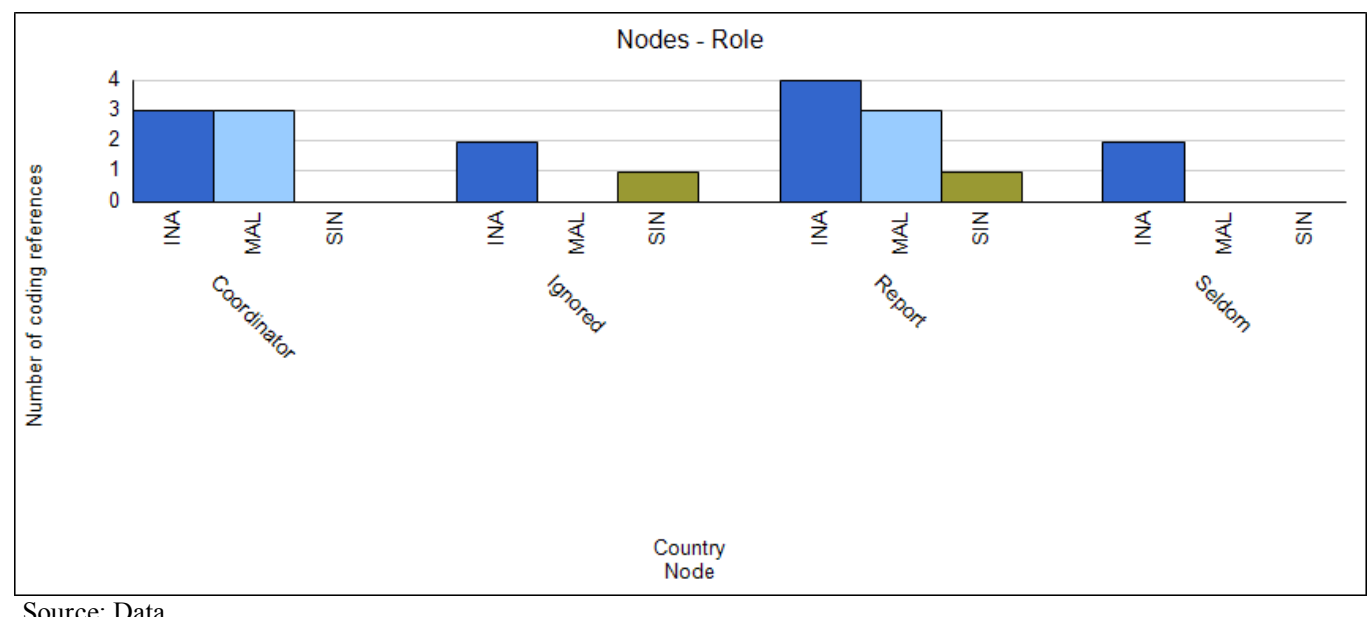

Figure 3. Government Evaluation - Role

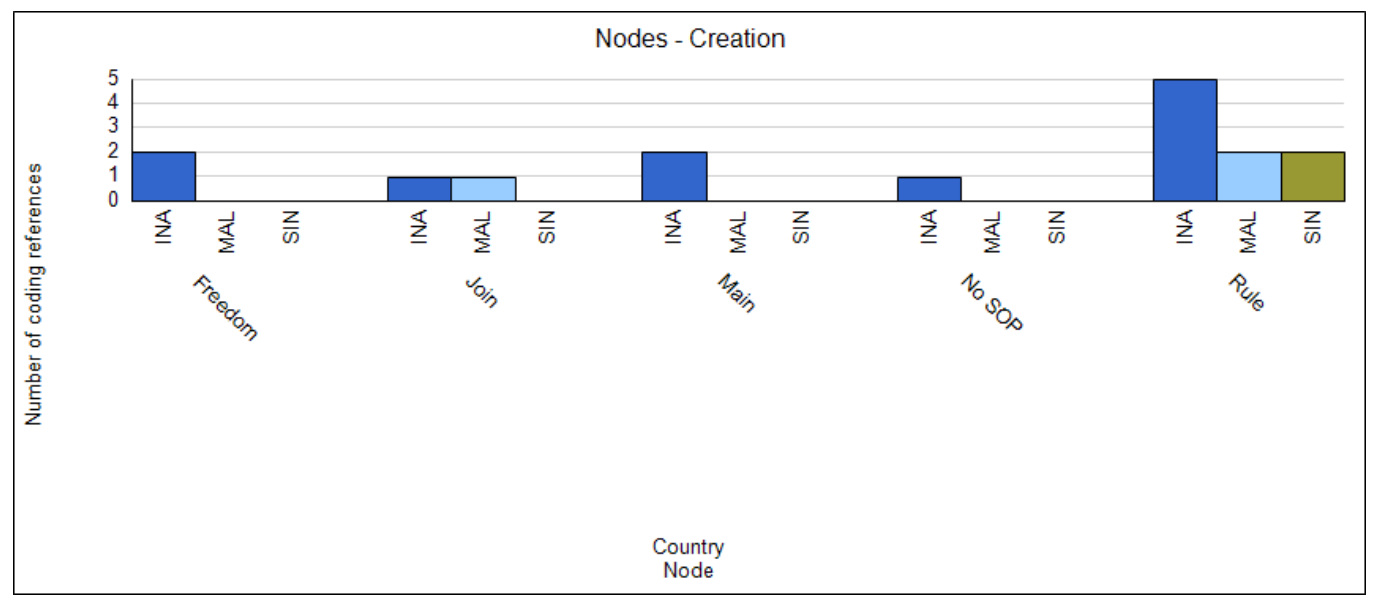

Source: Data

Figure 4. Purposes and boundaries of accountability - Creation

\subsection{Purposes and boundaries of accountability}

Dimension of purposes and boundaries of accountability describes accountability for stakeholders. In creation aspect, Indonesia has different views such as "freedom" in proposing idea, "main" accountability in the endowment institution, and "No SOP" to propose creation in the endowment institution (see figure 4).

In stakeholder aspect, each country may share similar issue in each node. Only Indonesian endowment institutions do not involve stakeholder in preparing strategic plan of endowment institution. In compliance aspect, all countries concern on "standard" which means that in proposing programs of endowment institutions, they have specific standard to be complied with. While Malaysia can accommodate stakeholder in preparing their programs, in Indonesia, only the management can prepare programs. 


\subsection{Shari'ah Compliance and Audit}

In the dimension of shari'ah compliance and audit, two important aspects are raised. They are supervision and shari'ah audit. It is only in Indonesia that "not available" node occurred. Supervision may not be conducted due to the limitation of human resource. This should not be occurring as endowment institution need careful evaluation. Shari'ah audit in most observed countries is performed by expert judgment with internal meeting. This however is an important issue to see the compliance to Islamic teaching.

From the analysis above, although all institutions are under government authority, Malaysian waqf institutions have similar accountability characteristics to Indonesian waqf institutions. In Malaysia, the reporting is based on federal government jurisdiction. Therefore, each state may have different emphasis. Meanwhile Singaporean waqf institutions may tend to be unitary logic. The institution is based on highly regulated structure, elite dominance, and hierarchical structure. However, stakeholders may have an opportunity to propose their program. This institution may only focus on reporting to Majelis Agama Islam Singapore (MUIS) as the parent institution (see table 4).

Table 4. Dimension and Aspect of Accountability

\begin{tabular}{|c|c|c|c|}
\hline Dimension & Indonesia & Malaysia & Singapore \\
\hline Control and conflict & $\begin{array}{l}\text { The government is more } \\
\text { regulated } \\
\text { Conflict is common in private } \\
\text { Change is inevitable }\end{array}$ & $\begin{array}{l}\text { Having own procedure } \\
\text { Staff level less involved } \\
\text { Flexible to innovate }\end{array}$ & $\begin{array}{l}\text { Procedure basis } \\
\text { Limited conflict } \\
\text { Regulation compliance }\end{array}$ \\
\hline \multirow[t]{3}{*}{ Elites } & $\begin{array}{l}\text { Decision by elites and } \\
\text { participation in priorities }\end{array}$ & Decision by elites & Decision by elites \\
\hline & $\begin{array}{l}\text { Private emphasizes partnership } \\
\text { and flexibility }\end{array}$ & Hierarchy basis and flexible & Hierarchy basis \\
\hline & Private is borderless. & Free to express & Limited interaction \\
\hline \multirow[t]{2}{*}{ Government evaluation } & $\begin{array}{l}\text { The government as coordinator } \\
\text { and proactive in monitoring }\end{array}$ & Based on jurisdiction & No role \\
\hline & $\begin{array}{l}\text { Government must be active in } \\
\text { evaluation }\end{array}$ & By Federal government & Internal supervision \\
\hline \multirow{3}{*}{$\begin{array}{l}\text { Purposes and boundaries of } \\
\text { accountability }\end{array}$} & Based on priority and regulation & Regulation basis & Rule based \\
\hline & $\begin{array}{l}\text { Program alignment with internal } \\
\text { Management authority }\end{array}$ & Stakeholder can propose & Stakeholder can propose \\
\hline & & Standard for proposal & Comply to standard \\
\hline \multirow[t]{2}{*}{ Shari'ah compliance and audit } & Formal shari'ah supervision & Federal state supervision & Expert judgment \\
\hline & Internal shari'ah audit & Internal shari'ah audit & Review \\
\hline
\end{tabular}




\section{Conclusion}

The characteristic of logic accountability of Malaysian waqf institutions may be similar to Indonesian waqf institutions. In Malaysia, waqf institutions are under the federal government institution but they are like state-owned companies. Their objective is to generate income as much as possible. Their operational system is not so strict and rigid like in the government

office. Meanwhile in Singapore, as the waqf institution has developed into a big organization, the logic accountability may be similar to unitary logic. This may be since the fund-raising unit is from Majelis Agama Islam Singapore (MUIS). Therefore, the accountability focuses on this institution. In addition, this institution is based on corporate scheme. Therefore, the mechanism may refer to modern company management like insurance, pension fund and mutual fund company.

\section{References}

Bradshaw, P., Hayday, B. and Armstrong, R. (2007), "Non-profit governance models: Problems and prospects", The Innovation Journal: The Public Sector Innovation Journal, Vol. 12 No. 3, pp. 1-22.

Cordery, C. (2013) "Regulating small and medium charities: Does it improve transparency and accountability?", Voluntas, Vol.24, pp. 831-851.

Coule, T. M. (2013), "Nonprofit governance and accountability: Broadening the theoretical perspective", Nonprofit and Voluntary Sector Quarterly, Vol. XX No. X, pp. 1-23.

Ebrahim, A. (2005), “Accountability myopia: Losing sight of organizational learning”, Nonprofit and Voluntary Sector Quarterly, Vol. 34, pp. 56-87.

Fox, A. (1966), Industrial sociology and industrial relations, Royal Commission Research Paper No. 3, HMSO, London.

Fox, J. A. and Brown, L. D. (Ed.). (1998), The struggle for accountability: The World Bank, NGOs, and grassroots movements, MIT Press, Cambridge.

Iqbal, Z. and Lewis, M. K. (2009), An Islamic perspective on governance, Edward Elgar Publishing Limited, Cheltenham.

Leibowitz, M. L., Bova, A. and Hammond, P. B. (2010), The endowment model of investing: Return, risk, and diversification, John Wiley and Sons Inc., New Jersey.

Lincoln, Y.S. and Guba, E.G. (1985), Naturalistic Inquiry, Sage Publications, California.

Lipman, F. D. and Lipman, L. K. (2006), Corporate governance best practices,John Wiley and Sons Inc., New Jersey.

Olson, R. L. (2003). Investing in pension funds \& endowments. New York: The McGrawHill Sawant, R. J. (2010), Infrastructure investing, John Wiley and Sons Inc., New Jersey. 
Siswantoro, D. and Rosdiana, H. (2016). Reconstructing cash waqf (Endowment) institution accountability in Indonesia: A case study. Asia Pacific Research in Social Sciences and Humanities.

Tremblay-Boire, J., \& Prakash, A. (2014). Accountability.org: Online disclosure by U.S. nonprofits. Voluntas, 26, 692-719. 